\title{
PENGARUH RELIGIOSITAS, PERILAKU TIDAK ETIS, DAN KEEFEKTIFAN PENGENDALIAN INTERNAL TERHADAP KECENDERUNGAN KECURANGAN AKUNTANSI (STUDI EMPIRIS PADA BANK UMUM SYARIAH DI KOTA BANDA ACEH)
}

\author{
Zuhra Maulidya $^{1}$, Yulia Fitri* ${ }^{* 2}$ \\ ${ }^{1,2}$ Program Studi Akuntansi Fakultas Ekonomi dan Bisnis Universitas Syiah Kuala \\ e-mail: zuhramaulidya@gmail.com ${ }^{1}$, yfitri.fekon@ unsyiah.ac.id ${ }^{2}$
}

\section{* Corresponding Author}

\begin{abstract}
Abstrak
The purpose of this research is to examine the influence of religiosity, unethical behavior, and effectiveness of internal control to tendency of accounting fraud (Empirical Study on Islamic Bank in the city of Banda Aceh). The population of this study were the managers and internal auditors of Islamic bank with the total 33 respondents. The research was conducted by using census method. The data source in this study are primary data obtained from questionnaires to the respondent. The testing of the influences of independent variables toward dependent variables was done by using multiple linear regressions model. The results of this research showed that both partially and simultaneously, religiosity, unethical behavior, and effectiveness of internal control were significantly influential to the accounting fraud on Islamic bank in the city of Banda Aceh.
\end{abstract}

Keywords: Tendency of Accounting Fraud, religiosity, unethical behavior, and effectiveness of internal control

\section{Pendahuluan}

Menurut UU No. 21 tahun 2008 tentang perbankan syariah, bank syariah adalah bank yang menjalankan kegiatan usaha berdasarkan prinsip syariah, atau prinsip hukum Islam yang diatur dalam fatwa Majelis Ulama Indonesia seperti prinsip keadilan dan keseimbangan, kemaslahatan, universalisme, serta tidak mengandung gharar, maysir, riba, zalim dan obyek yang haram. Sebagai lembaga yang berpedoman pada hukum Islam, lembaga keuangan syariah dituntut untuk memiliki performa lebih baik di mata masyarakat sehingga masyarakat tertarik untuk menginvestasikan dananya pada bank syariah. Dengan berlandaskan hukum Islam dan menggunakan sistem bagi hasil, bank syariah diharapkan mampu mencapai tujuan-tujuan yaitu demi kemaslahatan umat (Junita, 2016). Namun, seiring dengan berkembangnya industri perbankan di Indonesia, berbagai macam kasus kecurangan menodai perkembangan tersebut. Berdasarkan catatan OJK menyatakan bahwa kasus kecurangan atau tindak pidana perbankan di Indonesia masih cukup tinggi. Hingga akhir triwulan III-2016, OJK mencatat ada 26 kasus tindak pidana perbankan, yang sebagian besar terjadi pada kasus kredit 55\%, rekayasa pencatatan $21 \%$, penggelapan dana $15 \%$, transfer dana $5 \%$, dan pengadaan aset $4 \%$. OJK juga memastikan sebagian besar kasus pembobolan dan kecurangan perbankan selalu melibatkan orang dalam (Egita, 2018). Kecurangan merupakan perbuatan yang dilakukan dengan berbagai cara licik dan bersifat menipu serta sering tidak disadari oleh korban yang dirugikan. Kecurangan di bidang perbankan dapat diartikan sebagai tindakan sengaja melanggar ketentuan internal (kebijakan, sistem, dan prosedur) dan peraturan perundang-undangan yang berlaku demi kepentingan pribadi atau pihak lain yang berpotensi merugikan bank dan pihak-pihak terkait baik material maupun moril (Egita, 2018).

Faktor-faktor yang mempengaruhi kecenderungan kecurangan akuntansi salah satunya adalah religiositas. Rohayati (2014), menyatakan bahwa religiositas seseorang dapat berpengaruh terhadap kinerja mereka di dalam perusahaan. Sikap religiositas yang di miliki setiap individu, akan menjadi batasan dalam menjalankan persaingan 
dalam dunia kerja. Religiositas mendorong setiap individu senantiasa bersikap lebih bijak dalam menghadapi tantangan pekerjaan.

Faktor lain yang mempengaruhi kecenderungan kecurangan akuntansi adalah perilaku tidak etis. Dijk (2009:297) dalam Thoyibatun (2009) menjelaskan perilaku tidak etis adalah perilaku yang menyimpang dari tugas pokok atau tujuan utama yang telah disepakati. Menurut Beu dan Buckley (2001) perilaku tidak etis semestinyanya tidak bisa diterima secara kesusilaan karena menimbulkan bahaya bagi orang lain dan lingkungan.

Faktor lain yang mempengaruhi kecenderungan kecurangan akuntansi adalah keefektifan pengendalian internal. Menurut PP No. 8 Tahun 2006 pengendalian internal adalah suatu proses yang dipengaruhi oleh manajemen yang diciptakan untuk memberikan keyakinan yang memadai dalam pencapaian efektivitas, efisiensi, ketaatan terhadap peraturan perundang-undangan yang berlaku dan keandalan penyajian laporan keuangan.

Berdasarkan pemaparan di atas, maka peneliti tertarik untuk melakukan penelitian dengan judul "Pengaruh Religiositas, Perilaku Tidak Etis, dan Keefektifan Pengendalian Internal terhadap Kecenderungan Kecurangan Akuntansi (Studi Empiris Pada Bank Umum Syariah di Kota Banda Aceh)"

\section{Kerangka Teoritis Dan Pengembangan Hipotesis}

\section{Kecenderungan Kecurangan Akuntansi}

Dalam Association of Certified Fraud Examiners (ACFE, 2016) kecurangan adalah perbuatan melawan hukum yang dilakukan dengan sengaja untuk tujuan tertentu (manipulasi atau memberikan laporan keliru kepada pihak lain) yang dilakukan oleh orang-orang dari dalam atau luar organisasi untuk mendapatkan keuntungan pribadi. Menurut Thoyibatun (2009) kecenderungan kecurangan akuntansi diartikan sebagai adanya tindakan, kebijakan, cara, kelicikan, penyembunyian, dan penyamaran yang tidak semestinya secara sengaja, yaitu dalam menyajikan laporan keuangan dan pengelolaan aset organisasi yang mengarah pada tujuan mencapai keuntungan bagi dirinya sendiri dan menjadikan pihak yang lain sebagai pihak yang dirugikan.

\section{Religiositas}

Religiositas menurut McDaniel dan Burnett (1990) adalah kepercayaan kepada Tuhan disertai dengan komitmen untuk mengikuti prinsip-prinsip yang diyakini ditetapkan oleh Allah. Religiositas menurut suhargiyanto (2001) adalah hubungan individu dengan Ilahi Yang Maha Kuasa, Maha Pengasih, dan Maha Penyayang yang berkonsekuensi untuk melaksanakan kehendak-Nya dan menjauhi yang tidak dikehendaki-Nya (larangan-Nya).

\section{Perlikau Tidak Etis}

Buckley et al., (2001) menyatakan bahwa perilaku tidak etis merupakan suatu pola tingkah laku yang salah, yang dilakukan secara sadar dan menjadi tradisi di suatu bagian organisasi. Menurut Irphani (2017) kondisi di lapangan menyebutkan bahwa perilaku tidak etis merupakan asas perilaku menyimpang yang disepakati atau dibenarkan maupun perilaku salah yang dilakukan secara terus menerus sehingga umum untuk dilakukan.

\section{Keefektifan Pengendalian Internal}

Menurut PP No. 8 tahun 2006 pengendalian internal adalah suatu proses yang dipengaruhi oleh manajemen yang diciptakan untuk memberikan keyakinan yang memadai dalam pencapaian efektivitas, efisiensi, ketaatan terhadap peraturan perundang-undangan yang berlaku, dan keandalan penyajian laporan keuangan. Sedangkan menurut Committee of Sponsoring Organizations of the Treadway Commission (COSO, 2013) pengendalian internal adalah representatif dari keseluruhan kegiatan di dalam organisasi yang harus dilaksanakan, dimana proses yang dijalankan oleh dewan komisaris yang ditujukan untuk memberikan keyakinan yang memadai tentang pencapaian tujuan pengendalian operasional yang efektif dan efisien, keandalan laporan keuangan, dan kepatuhan terhadap hukum yang berlaku.

\section{Pengaruh Religiositas Terhadap Kecenderungan Kecurangan Akuntansi}

Definisi religiositas seperti yang di definisikan oleh McDaniel dan Burnett (1990) adalah kepercayaan kepada tuhan disertai dengan komitmen untuk mengikuti prinsip-prinsip yang diyakini ditetapkan oleh Allah. Basri (2015) menyatakan bahwa agama dipercaya dapat mengontrol perilaku individu dari 
sikap yang tidak etis. Seseorang yang memiliki sikap religiositas yang tinggi cenderung berperilaku etis dan menghindari perilaku kecurangan. Keyakinan agama yang kuat diharapkan dapat mencegah perilaku illegal melalui perasaan bersalah terutama dalam hal berbuat curang (Grasmick et al., 1991). Hal ini ditunjukkan dengan penelitian yang dilakukan oleh Egita (2018) yang menyatakan bahwa religiositas berpengaruh signifikan terhadap kecurangan.

H1: Religiositas berpengaruh terhadap kecenderungan kecurangan akuntansi

\section{Pengaruh Perilaku Tidak Etis Terhadap Kecenderungan Kecurangan Akuntansi}

Buckley at al., (1998) menjelaskan bahwa perilaku tidak etis merupakan sesuatu pola tingkah laku yang salah, yang dilakukan secara sadar dan menjadi tradisi di suatu bagian organisasi. Kondisi di lapangan menyebutkan bahwa perilaku tidak etis merupakan asas perilaku menyimpang yang disepakati atau dibenarkan maupun perilaku salah yang dilakukan secara terus menerus sehingga umum dilakukan. Hal ini ditunjukkan dengan penelitian yang dilakukan oleh Rizky dan Fitri (2017), Rahmi dan Sovia (2017), Nurlaeliyah dan Anisykurlillah (2017), dan Mustika (2016) yang menyatakan bahwa perilaku tidak etis berpengaruh signifikan terhadap kecurangan.

H2: Perilaku tidak etis berpengaruh terhadap kecenderungan kecurangan akuntansi

\section{Pengaruh Keefektifan Pengendalian Internal Terhadap Kecenderungan Kecurangan Akuntansi}

Mulyadi (2002:165) menyatakan bahwa pengendalian internal adalah sistem pengendalian yang meliputi struktur organisasi, metode, dan ukuranukuran yang dikoordinasikan untuk menjaga kekayaan organisasi, mengecek ketelitian dan keandalan data akuntansi. Hal ini ditunjukkan dengan penelitian yang dilakukan oleh Rizky dan Fitri (2017), dan Nurlaeliyah dan Anisykurlillah (2017) menyatakan bahwa Keefektifan pengendalian internal memberikan pengaruh signifikan terhadap kecurangan.

H3: Keefektifan pengendalian internal berpengaruh terhadap kecenderungan kecurangan akuntansi

Berdasarkan penjelasan diatas, maka skema kerangka pemikiran dapat digambarkan sebagai berikut.

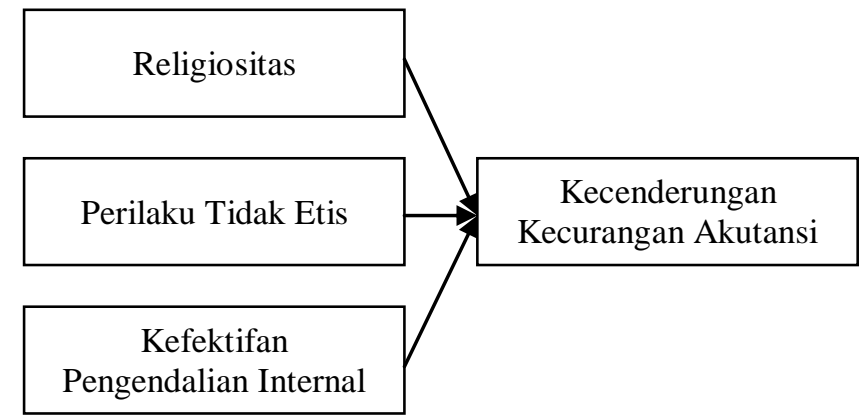

Gambar 1 Skema Kerangka Pemikiran

\section{Metode Penelitian \\ Desain Penelitian}

Penelitian ini merupakan penelitian kuantitatif. Tujuan studi yang dilakukan dalam penelitian ini bersifat kausal dengan menguji hipotesis. Tingkat intervensi dalam penelitian ini minimal, penelitian ini mengunakan penelitian survei. Horizon waktu yang digunakan dalam penelitian ini adalah cross sectional.

\section{Populasi dan Sampel Penelitian}

Populasi yang akan digunakan dalam penelitian ini adalah manajer tingkat menengah, manajer tingkat pertama dan audit internal di Bank Umum Syariah (BUS) di Kota Banda Aceh yang berjumlah 6 BUS. Sedangkan jumlah manajer tingkat menengah, manajer tingkat pertama dan audit internal yang menjadi responden adalah 33 orang. Teknik pengambilan sampel dalam penelitian ini adalah sampling jenuh.

\section{Operasional Variabel}

\section{Kecenderungan Kecurangan Akuntansi (Y)}

Kecenderungan kecurangan akuntansi adalah tindakan, kebijakan, dan cara, kelicikan, penyembunyian, dan penyamaran yang tidak semestinya secara sengaja, yaitu dalam menyajikan laporan keuangan dan mengelola aset organisasi yang mengarah pada tujuan mencapai keuntungan bagi dirinya sendiri dan menjadikan yang lain sebagai pihak yang dirugikan (Thoyibatun, 2012). Instrumen yang digunakan untuk mengukur kecenderungan kecurangan akuntansi dikembangkan berdasarkan jenis-jenis kecurangan menurut Association of Certified Fraud Examiners (ACFE), yang terdiri dari kecurangan laporan keuangan, penyalahgunaan aset, dan korupsi. Variabel kecenderungan kecurangan 
akuntansi diukur menggunakan kuesioner yang terdiri dari sepuluh item pertanyaan.

\section{Religiositas (X1) \\ Metode Analisis}

Religiositas merupakan suatu sistem yang terintegrasi dari keyakinan, gaya hidup, aktivitas ritual dan intuisi yang memberikan makna dalam kehidupan manusia dan mengarahkan manusia pada nilai-nilai suci atau nilai-nilai tertinggi (Glock \& Stark, 1965). Instrumen yang digunakan untuk mengukur religiositas dikembangkan oleh Glock dan Stark (1965) yang terdiri dari lima indikator yaitu praktik agama (religious practice), keyakinan (religious belief), pengetahuan agama (religious knowledge), penghayatan agama (religious feeling), dan pengamalan agama (religious effect). Variabel religiositas diukur menggunakan kuesioner yang terdiri dari sembilan item pertanyaan. Pengukuran variabel menggunakan skala likert dengan lima point, yaitu: $1=$ Sangat tidak setuju, $2=$ Tidak setuju, $3=$ Netral, 4= Setuju, 5= Sangat setuju.

\section{Perilaku Tidak Etis (X2)}

Menurut Griffin dan Ebert (2007:58) perilaku tidak etis adalah perilaku yang tidak sesuai dengan norma-norma sosial yang diterima secara umum, sehubungan dengan tindakan yang bermanfaat atau yang membahayakan. Instrumen yang digunakan untuk mengukur perilaku tidak etis dikembangkan oleh Robinson dan Bennet (1995), yang terdiri dari lima indikator yaitu perilaku manajemen yang menyalahgunakan kedudukan (abuse position), perilaku manajemen yang menyalahgunakan sumber daya organisasi (abuse resources), perilaku manajemen yang menyalahgunakan kekuasaan (abuse power), perilaku manajemen yang tidak berbuat apa-apa (no action), dan perilaku manajemen yang mengabaikan peraturan (abuse rule). Variabel perilaku tidak etis diukur menggunakan kuesioner yang terdiri dari lima item pertanyaan. Pengukuran variabel menggunakan skala likert dengan lima point, yaitu: 1=Sangat tidak setuju, $2=$ Tidak setuju, $3=$ Netral, $4=$ Setuju, 5= Sangat setuju.

\section{Kefektifak Pengendalian Internal (X3)}

Menurut mulyadi (2002:165) pengendalian internal merupakan sistem pengendalian yang meliputi struktur organisasi, metode, dan ukuran-ukuran yang dikoordinasikan untuk menjaga kekayaan organisasi, mengecek ketelitian, dan keandalan data akuntansi. Instrumen yang digunakan untuk mengukur keefektifan pengendalian internal di kembangkan oleh COSO (2013) yang terdiri dari lima indikator yaitu lingkungan pengendalian, penaksiran risiko, aktivitas pengendalian, informasi dan komunikasi, pemantauan. Variabel keefektifan pengendalian internal diukur menggunakan kuesioner yang terdiri dari lima item pertanyaan. Pengukuran variabel menggunakan skala likert dengan lima point, yaitu: $1=$ Sangat tidak setuju, $2=$ Tidak setuju, $3=$ Netral, $4=$ Setuju, $5=$ Sangat setuju.

\section{Teknik Pengumpulan Data}

Data primer dalam penelitian ini diperoleh dengan menyebarkan kuesioner yang berisi pertanyaan yang terkait dengan variabel penelitian kepada responden yang telah ditentukan sebelumnya. Agar penyebaran kuesioner lebih efektif, peneliti sendiri yang langsung mengantarkan kuesioner kepada responden dan akan diambil kembali jika kuesioner sudah selesai diisi sesuai dengan waktu yang telah disepakati antar peneliti dan responden demi menghindari kuesioner yang tidak kembali.

\section{Metode Penelitian}

Alat analisis yang digunakan dalam penelitian ini adalah analisis regresi linier berganda bertujuan untuk mengetahui pengaruh atau hubungan antara variabel bebas yaitu: Religiositas (X1), perilaku tidak etis (X2), dan Keefektifan pengendalian internal (X3) terhadap variabel terikat yaitu kecenderungan kecurangan akuntansi (Y). Perhitungan statistik dalam analisis regresi linier berganda yang dilakukan dalam penelitian ini adalah dengan menggunakan bantuan program SPSS.

Persamaan regresi linier berganda adalah sebagai berikut (Ghozali, 2016):

$$
\mathrm{Y}=\mathrm{a}+\mathrm{b} 1 \mathrm{X} 1+\mathrm{b} 2 \mathrm{X} 2+\mathrm{b} 3 \mathrm{X} 3+\mathrm{e}
$$

Keterangan:

$$
\begin{aligned}
& \mathrm{Y}=\text { Kecenderungan Kecurangan Akuntansi } \\
& \alpha=\text { Konstanta } \\
& \mathrm{b} \quad=\text { Koefisien Regresi }
\end{aligned}
$$


$\mathrm{X} 1$ = Religiositas

$\mathrm{X} 2=$ Perilaku Tidak Etis

X3 = Keefektifan Pengendalian Internal

$\varepsilon \quad=$ Error

\section{Hasil Dan Pembahasan}

\section{Uji Kualitas Data}

\section{Hasil Uji Validitas}

Pengujian kualitas data dalam penelitian ini diuji secara statistik menggunakan uji koefisien korelasi product moment dengan nilai signifikansi sebesar 0,05 dibantu oleh SPSS 21. Butir pertanyaaan tersebut dikatakan valid apabila nilai $\mathrm{r}$ hitung lebih besar dari pada nilai $r$ tabel. Begitupun sebaliknya, jika $r$ hitung lebih kecil dari pada $r$ tabel, maka butir pertanyaan tersebut dikatakan tidak valid.

\begin{tabular}{|c|c|c|c|c|}
\hline Variabel & Indikator & $\begin{array}{c}\text { Koefisien } \\
\text { Korelasi (R } \\
\text { hitung) }\end{array}$ & $\begin{array}{c}\text { Nilai Kritis } \\
5 \%(R \\
\text { tabel) }\end{array}$ & Ket \\
\hline \multirow[t]{9}{*}{ Religiositas } & $\mathrm{X} 1$ & 0,754 & \multirow[t]{9}{*}{0.344} & Valid \\
\hline & $\mathrm{X} 2$ & 0,744 & & Valid \\
\hline & X3 & 0,802 & & Valid \\
\hline & $\mathrm{X} 4$ & 0,701 & & Valid \\
\hline & $\mathrm{X} 5$ & 0,686 & & Valid \\
\hline & X6 & 0,581 & & Valid \\
\hline & $\mathrm{X} 7$ & 0,552 & & Valid \\
\hline & $\mathrm{X} 8$ & 0,714 & & Valid \\
\hline & $\mathrm{X} 9$ & 0,521 & & Valid \\
\hline \multirow{5}{*}{$\begin{array}{l}\text { Perilaku } \\
\text { Tidak Etis }\end{array}$} & $\mathrm{X} 1$ & 0,880 & \multirow[t]{5}{*}{0.344} & Valid \\
\hline & $\mathrm{X} 2$ & 0,937 & & Valid \\
\hline & $\mathrm{X} 3$ & 0,881 & & Valid \\
\hline & $\mathrm{X} 4$ & 0,827 & & Valid \\
\hline & X5 & 0,843 & & Valid \\
\hline \multirow{5}{*}{$\begin{array}{l}\text { Keefektifan } \\
\text { Pengendalia } \\
\text { n Internal }\end{array}$} & $\mathrm{X} 1$ & 0,897 & \multirow[t]{5}{*}{0.344} & Valid \\
\hline & $\mathrm{X} 2$ & 0,908 & & Valid \\
\hline & X3 & 0,987 & & Valid \\
\hline & $\mathrm{X} 4$ & 0,987 & & Valid \\
\hline & X5 & 0,944 & & Valid \\
\hline \multirow{10}{*}{$\begin{array}{l}\text { Kecenderung } \\
\text { a n n } \\
\text { Kecurangan } \\
\text { Akuntansi }\end{array}$} & Y1 & 0,536 & \multirow[t]{10}{*}{0.344} & Valid \\
\hline & Y2 & 0,542 & & Valid \\
\hline & Y3 & 0,693 & & Valid \\
\hline & Y4 & 0,869 & & Valid \\
\hline & Y5 & 0,842 & & Valid \\
\hline & Y6 & 0,811 & & Valid \\
\hline & Y7 & 0,802 & & Valid \\
\hline & Y8 & 0,871 & & Valid \\
\hline & Y9 & 0,856 & & Valid \\
\hline & Y10 & 0,744 & & Valid \\
\hline
\end{tabular}

Hasil Uji Reliabilitas

\begin{tabular}{|l|c|c|c|}
\hline \multicolumn{1}{|c|}{ Variabel } & $\begin{array}{c}\text { Cronbach } \\
\text { Alpha }\end{array}$ & $\begin{array}{c}\text { Nilai kritis } \\
\text { Cronbach } \\
\text { Alpha }\end{array}$ & Ket \\
\hline Religiositas (X1) & 0,849 & 0,60 & Reliabel \\
\hline $\begin{array}{l}\text { Perilaku Tidak etis } \\
\text { (X2) }\end{array}$ & 0,911 & 0,60 & Reliabel \\
\hline $\begin{array}{l}\text { Keefektifan } \\
\text { Pengendalian }\end{array}$ & 0,969 & 0,60 & Reliabel \\
\hline $\begin{array}{l}\text { Kecenderungan } \\
\text { Kecurangan } \\
\text { Akuntansi (Y) }\end{array}$ & 0,914 & 0,60 & Reliabel \\
\hline
\end{tabular}

Berdasarkan tabel di atas, hasil uji reliabilitas menghasilkan nilai Cronbach Alpha masing-masing variabel yang lebih besar dari 0.60. dapat disimpulkan bahwa kuesioner pada penelitian ini dapat mencapai tujuan penelitian.

\section{Uji Asumsi Klasik} Hasil Uji Normalitas

\begin{tabular}{|l|c|}
\hline & Unstandardized Residual \\
\hline Asymp. Sig. (2-tailed) & 0,291 \\
\hline
\end{tabular}

Dapat dilihat bahwa nilai signifikansi (Asymp. Sig. 2- tailed) sebesar 0,291. Nilai signifikansi lebih dari 0,05 , maka data tersebut terdistribusi secara normal.

\section{Hasil Uji Multikolinearitas}

\begin{tabular}{|l|c|c|}
\hline \multicolumn{1}{|c|}{ Model } & Tolerance & VIP \\
\hline Religiositas & 0,853 & 1,173 \\
\hline $\begin{array}{l}\text { Perilaku Tidak } \\
\text { Etis }\end{array}$ & 0,743 & 1,345 \\
\hline $\begin{array}{l}\text { Keefektifan } \\
\text { Pengendalian } \\
\text { Internal }\end{array}$ & 0,800 & 1.249 \\
\hline
\end{tabular}

Pendeteksian multikolinearitas dapat dilakukan dengan melihat nilai Variance Inflasting Factor (VIF) dan nilai tolerance. Apabila nilai tolerance $>0,10$ dan nilai VIF <10, maka tidak terjadi multikolinearitas. Maka dapat disimpulkan bahwa tidak terjadi multikolinearitas. Hal ini dapat dibuktikan dengan masing-masing model memiliki nilai tolerance yang > 0,10 dan nilai $\mathrm{VIP}<10$. 


\section{Hasil Uji Heteroskedastisitas}

Scatterplot

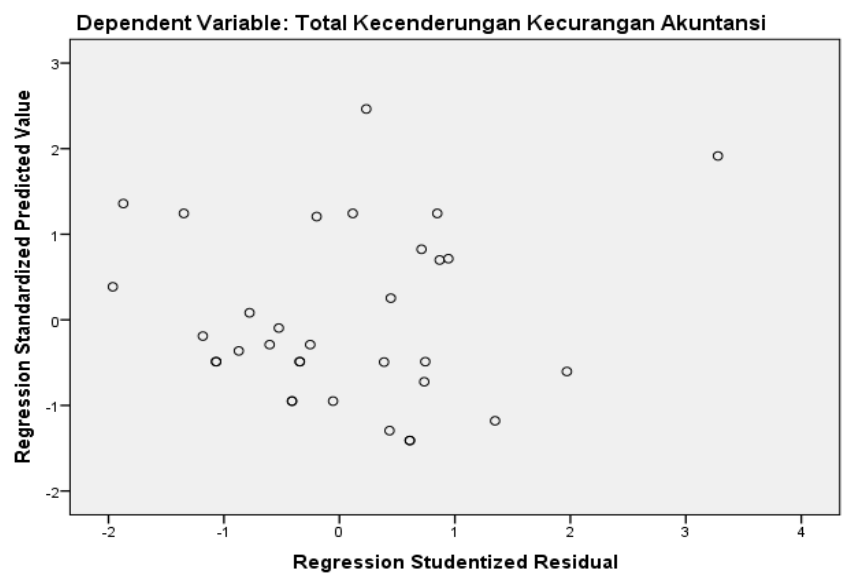

Pola pada grafik scatterplot dapat melihat apakah model regresi mengalami heterokedastisitas. Jika tidak terdapat pola tertentu atau titik-titik menyebar diatas dan dibawah angka 0 pada sumbu Y, maka tidak terjadi heterokedastisitas (Ghozali, 2016). Dapat dilihat bahwa tidak terdapat pola tertentu atau titik-titik yang menyebar di atas dan di bawah angka 0 pada sumbu Y, maka model regresi pada penelitian ini tidak terjadi heteroskedastisitas.

\section{Metode Analisis dan Rancangan Pengujian Hipotesis}

Metode Analisis Regresi Linear Berganda

\begin{tabular}{|c|c|c|c|c|c|}
\hline \multirow{2}{*}{ Model } & \multicolumn{2}{|c|}{ Unstandardized Coefficients } & \multirow{2}{*}{$\begin{array}{c}\text { Standardized Coefficients } \\
\text { Beta }\end{array}$} & \multirow{2}{*}{$\mathrm{T}$} & \multirow{2}{*}{ Sig } \\
\hline & B & Std. Error & & & \\
\hline 1 (constant) & 47,266 & 10,156 & & 4,654 & 0,000 \\
\hline Religiositas & $-0,448$ & 0,181 & $-0,287$ & $-2,468$ & 0,020 \\
\hline Perilaku Tidak Etis & 1,039 & 0,218 & 0,596 & 4,775 & 0,000 \\
\hline Keefektifan Pengendalian Internal & $-0,936$ & 0,257 & $-0,438$ & $-3,656$ & 0,001 \\
\hline
\end{tabular}

Berdasarkan perhitungan statistik yang disajikan pada Tabel di atas maka menghasilkan persamaan regresi linear berganda sebagai berikut:

$$
\mathrm{Y}=47,266-0,448 \mathrm{X} 1+1,039 \mathrm{X} 2-0,936 \mathrm{X} 3+e
$$

Nilai konstansta sebesar 47,266 menunjukan bahwa apabila variabel religiositas, perilaku tidak etis, dan keefektifan pengendalian internal dianggap konstan, maka variabel kecenderungan kecurangan akuntansi bernilai positif sebesar 47,266.

Nilai religiositas (X1) sebesar 0,448 dan negatif, apabila religiositas meningkat sebesar $1 \%$, maka akan menurunkan tingkat kecenderungan kecurangan akuntansi sebesar 44,8\% dengan menggunakan asumsi untuk variabel bebas lain sama dengan nol atau konstan.

Nilai perilaku tidak etis (X2) sebesar 1,039 dan positif, apabila perilaku tidak etis meningkat sebesar $1 \%$, maka akan meningkatkan tingkat kecenderungan kecurangan akuntansi sebesar 103,9\% dengan menggunakan asumsi untuk variabel bebas lain sama dengan nol atau konstan.
Nilai keefektifan pengendalian internal (X3) sebesar 0,936 dan negatif, apabila keefektifan pengendalian internal meningkat sebesar $1 \%$, maka akan menurunkan tingkat kecenderungan kecurangan akuntansi sebesar 93,6\% dengan menggunakan asumsi untuk variabel lain sama dengan nol atau konstan

\section{Pengujian Hipotesis}

Pengujian secara Simultan (Uji Statistik F)

\begin{tabular}{|l|c|c|c|c|c|}
\hline \multicolumn{1}{|c|}{ Model } & $\begin{array}{r}\text { Sum of } \\
\text { Square }\end{array}$ & df & $\begin{array}{c}\text { Mean } \\
\text { Square }\end{array}$ & F & Sig \\
\hline Regression & 483,929 & 3 & 161,310 & 19,148 & 0,000 \\
\hline Residual & 244,313 & 29 & 8,425 & & \\
\hline Total & 728,242 & 32 & & & \\
\hline
\end{tabular}

Nilai sig 0,000 artinya lebih kecil dari 0,05 sehingga hipotesis dapat diterima, maka dapat disimpulkan bahwa religiositas, perilaku tidak etis, dan keefektifan pengendalian internal berpengaruh secara simultan terhadap kecenderungan kecurangan akuntansi pada BUS di Kota Banda Aceh.

Pengujian Secara Parsial (Uji Statistik T)

\begin{tabular}{|c|c|c|c|c|c|}
\hline \multirow{2}{*}{ Model } & \multicolumn{2}{|c|}{ Unstandardized Coefficients } & \multirow{2}{*}{$\begin{array}{c}\text { Standardized Coefficients } \\
\text { Beta }\end{array}$} & \multirow[b]{2}{*}{$\mathrm{T}$} & \multirow{2}{*}{ Sig } \\
\hline & $\mathrm{B}$ & Std. Error & & & \\
\hline 1 (constant) & 47,266 & 10,156 & & 4,654 & 0,000 \\
\hline Religiositas & $-0,448$ & 0,181 & $-0,287$ & $-2,468$ & 0,020 \\
\hline Perilaku Tidak Etis & 1,039 & 0,218 & 0,596 & 4,775 & 0,000 \\
\hline
\end{tabular}




\begin{tabular}{|c|c|c|c|c|c|}
\hline \multirow{2}{*}{ Model } & \multicolumn{2}{|c|}{ Unstandardized Coefficients } & Standardized Coefficients & \multirow{2}{*}{$\mathrm{T}$} & \multirow{2}{*}{ Sig } \\
\hline & $\mathrm{B}$ & Std. Error & Beta & & \\
\hline Keefektifan Pengendalian Internal & $-0,936$ & 0,257 & $-0,438$ & $-3,656$ & 0,001 \\
\hline
\end{tabular}

H1: Religiositas berpengaruh terhadap kecurangan akuntansi

Berdasarkan Tabel diatas, nilai sigifikansi variabel ini sebesar 0,020 yang mana lebih kecil daripada 0,05, maka dengan ini hipotesis diterima. Artinya religiositas berpengaruh secara parsial terhadap kecenderungan kecurangan akuntansi. Jadi, dapat disimpulkan bahwa semakin religius perilaku yang di tunjukkan oleh manajemen dalam suatu instansi maka, kecenderungan kecurangan akuntansi yang terjadi akan berkurang.

H2: Perilaku Tidak Etis berpengaruh terhadap kecurangan akuntansi

Berdasarkan Tabel diatas, nilai sigifikansi variabel ini sebesar 0,000 yang mana lebih kecil daripada 0,05, maka dengan ini hipotesis kedua diterima. Artinya perilaku tidak etis berpengaruh secara parsial terhadap kecenderungan kecurangan akuntansi. Jadi, dapat disimpulkan bahwa semakin tidak etis perilaku yang di tunjukkan oleh manajemen dalam suatu instansi maka, kecenderungan kecurangan akuntansi yang terjadi akan meningkat.

H3: Keefektifan pengendalian internal berpengaruh terhadap kecurangan akuntansi.

Berdasarkan Tabel diatas, nilai sigifikansi variabel ini sebesar 0,001 yang mana lebih kecil daripada 0,05 , maka dengan ini hipotesis ketiga diterima. Artinya keefektifan pengendalian internal berpengaruh secara parsial terhadap kecenderungan kecurangan akuntansi. Jadi, dapat disimpulkan bahwa semakin efektif pengendalian internal suatu instansi maka, kecenderungan kecurangan akuntansi yang terjadi akan berkurang.

Koefisien Determinasi $\left(\mathbf{R}^{2}\right)$

\begin{tabular}{|c|c|c|c|}
\hline Model & R & R Square & $\begin{array}{c}\text { Adjusted R } \\
\text { Square }\end{array}$ \\
\hline 1 & 0,815 & 0,665 & 0,630 \\
\hline
\end{tabular}

Nilai koefisien determinasi $\left(\mathrm{R}^{2}\right)$ sebesar 0,665 atau $66,5 \%$. Hal ini berarti kecenderungan kecurangan akuntansi dapat dijelaskan oleh tiga variabel bebas yaitu religiositas, perilaku tidak etis, dan keefektifan pengendalian internal sebesar $66,5 \%$. Sisanya sebesar 0,335 atau $33,5 \%$ dijelaskan oleh faktor-faktor lain yang tidak diikutkan pada model penelitian ini.

\section{Pembahasan}

Pengaruh Religiositas, Perilaku Tidak Etis, dan Keefektifan Pengendalian Internal Terhadap Kecenderungan Kecurangan Akuntansi

Berdasarkan hasil pengujian statistik $\mathrm{F}$ secara simultan hasil penelitian menunjukkan bahwa religiositas, perilaku tidak etis, dan keefektifan pengendalian internal berpengaruh terhadap kecenderungan kecurangan akuntansi pada BUS di Kota Banda Aceh. Hal ini sesuai dengan hipotesis yang dibuat sebelumnya, yakni religiositas, perilaku tidak etis, dan keefektifan pengendalian internal berpengaruh secara bersama-sama terhadap kecenderungan kecurangan akuntansi. Dua variabel di atas yakni religiositas, dan keefektifan pengendalian internal dapat mengurangi tingkat terjadinya kecenderungan kecurangan akuntansi, sedangkan perilaku tidak etis dapat meningkatkan tingkat terjadinya kecenderungan kecurangan akuntansi pada BUS di Kota Banda Aceh

\section{Pengaruh Religiositas Terhadap Kecenderungan Kecurangan Akuntansi}

Berdasarkan hasil pengujian hipotesis, diperoleh nilai signifikansi untuk variabel religiositas sebesar 0,020 yang mana lebih kecil dari 0,05 , artinya variabel religiositas berpengaruh secara parsial terhadap tingkat terjadinya kecenderungan kecurangan akuntansi. Jadi artinya, jika semakin religius manajemen di dalam suatu entitas, maka tingkat terjadinya kecurangan akuntansi di dalam suatu entitas akan semakin berkurang. Hasil penelitian ini sejalan atau konsisten dengan hasil penelitian sebelumnya yang juga dijadikan referensi dalam penelitian ini, yaitu penelitian Egita dan Mahfiroh (2018) yang menyatakan bahwa religiositas berpengaruh negatif signifikan terhadap kecurangan. 
Rohayati (2014), menyatakan bahwa religiositas seseorang dapat berpengaruh terhadap kinerja mereka di dalam perusahaan. Sikap religiositas yang di miliki setiap individu, akan menjadi batasan dalam menjalankan persaingan dalam dunia kerja. Religiositas mendorong setiap individu senantiasa bersikap lebih bijak dalam menghadapi tantangan pekerjaan. Suatu perusahaan sebaiknya menyediakan kegiatan religi, kegiatan religi diharapkan dapat membantu membentuk akhlak karyawan dan semakin meningkatkan religiositas masing-masing karyawan sehingga dalam bekerja tidak akan melakukan hal buruk yang salah satunya adalah melakukan kecurangan.

\section{Pengaruh Perilaku Tidak Etis Terhadap Kecenderungan Kecurangan Akuntansi}

Berdasarkan hasil pengujian hipotesis, diperoleh nilai signifikansi untuk variabel perilaku tidak etis sebesar 0,000 yang mana lebih kecil dari 0,05, artinya variabel perilaku tidak etis berpengaruh secara parsial terhadap tingkat terjadinya kecenderungan kecurangan akuntansi. Jadi artinya, jika semakin tidak etis perilaku yang dilakukan oleh manajemen, maka tingkat terjadinya kecurangan akuntansi di dalam suatu entitas akan semakin meningkat. Hasil penelitian ini sejalan atau konsisten dengan hasil penelitian sebelumnya yang juga dijadikan referensi dalam penelitian ini, yaitu penelitian Rizky dan Fitri (2017) dan Rahmi dan Sovia (2017) yang menyatakan bahwa perilaku tidak etis berpengaruh positif signifikan terhadap kecenderungan kecurangan akuntansi.

Griffin dan Ronald (2007:58) menyatakan bahwa perilaku tidak etis adalah perilaku yang tidak sesuai dengan norma-norma sosial yang diterima secara umum, sehubungan dengan tindakan yang bermanfaat atau yang membahayakan, salah satunya tindak kecurangan yang membayakan keberlangsungan jalannya suatu perusahaan. Semakin tidak etis perilaku yang dilakukan oleh manajemen maka akan meningkatkan tingkat terjadinya kecurangan akuntansi.

\section{Pengaruh Keefektifan Pengendalian Internal Terhadap Kecenderungan Kecurangan Akuntansi}

Berdasarkan hasil pengujian hipotesis, diperoleh nilai signifikansi untuk variabel keefektifan pengendalian internal sebesar 0,001 yang mana lebih kecil dari 0,05, artinya variabel keefektifan pengendalian internal berpengaruh secara parsial terhadap tingkat terjadinya kecenderungan kecurangan akuntansi. Jadi artinya, jika semakin efektif pengendalian internal yang ada di dalam suatu entitas, maka tingkat terjadinya kecurangan akuntansi di dalam suatu entitas akan semakin berkurang. Hasil penelitian ini sejalan atau konsisten dengan hasil penelitian sebelumnya yang juga dijadikan referensi dalam penelitian ini, yaitu penelitian Rizky dan Fitri (2017) dan Nurlaeliyah dan Anisykurlillah (2017) yang menyatakan bahwa keefektifan pengendalian internal berpengaruh terhadap kecenderungan kecurangan akuntansi.

Dalam COSO (1992) pengendalian internal terdiri dari 5 komponen, yakni lingkungan.

\section{Kesimpulan, Keterbatasan Dan Saran Kesimpulan}

Kesimpulan dari hasil analisis dan pembahasan yang telah dijelaskan sebelumnya, adalah sebagai berikut:

1) Religiositas, perilaku tidak etis, dan keefektifan pengendalian internal secara bersama-sama berpengaruh terhadap kecenderungan kecurangan akuntansi pada BUS di Kota Banda Aceh.

2) Religiositas berpengaruh terhadap kecenderungan kecurangan akuntansi pada BUS di Kota Banda Aceh. Hal ini berarti menjelaskan bahwa semakin religious perilaku manajemen di suatu entitas bisnis, maka tingkat terjadinya kecenderungan kecurangan akuntansi akan berkurang.

3) Perilaku tidak etis berpengaruh terhadap kecenderungan kecurangan akuntansi pada BUS di Kota Banda Aceh. Hal ini berarti menjelaskan bahwa semakin etis perilaku manajemen di suatu entitas bisnis, maka tingkat terjadinya kecenderungan kecurangan akuntansi akan berkurang.

4) Keefektifan pengendalian internal berpengaruh terhadap kecenderungan kecurangan akuntansi pada BUS di Kota Banda Aceh. Berarti hal ini menjelaskan bahwa semakin efektif pengendalian internal di suatu entitas bisnis, maka tingkat terjadinya kecurangan akuntansi akan berkurang. 


\section{Implikasi Penelitian}

Terdapat beberapa keterbatasan yang dimiliki peneliti dalam melakukan penelitian, diantaranya sebagai berikut:

1. Pengumpulan data pada penelitian ini dilakukan dengan cara menyebar kuesioner, sehingga tidak menutup kemungkinan adanya persepsi yang berbeda dengan keadaan yang terjadi sebenarnya

\section{Keterbatasan}

Dalam melakukan penelitian ini penliti mengalami beberapa keterbatasan, diantaranya sebagai berikut:

1) Peneliti mengalami kesulitan dalam memperoleh data saat membagikan kuesioner kepada responden. Hal ini disebabkan oleh responden yang tidak ada di kantor biro wisata dan responden sering berangkat ke luar kota dalam rangka memberikan pelayanan kepada pelanggannya.

2) Keterbatasan waktu yang dimiliki oleh responden sehingga membuat proses pengumpulan data sedikit lebih lama.

3) Pengumpulan data dalam penelitian ini melalui kuesioner membuat tidak menutup kemungkinan adanya persepsi responden yang berbeda dengan keadaan yang sebenarnya.

\section{Saran}

\section{Saran Praktis}

Saran praktis yang dapat peneliti berikan antara lain adalah sebagai berikut:

Para manajer diharapkan terus meningkatkan

1) kesadaran dan juga pemahaman terhadap dampak yang ditimbulkan oleh kecurangan akuntansi pada masa yang akan datang, sehingga apa yang sudah direncanakan dapat dijalankan dengan tepat. Suatu perusahaan sebaiknya menyediakan kegiatan religi seperti adanya tausiah setiap selesai shalat asar berjamaah, kegiatan religi diharapkan dapat membantu membentuk akhlak karyawan dan semakin meningkatkan religiositas serta perilaku etis masing-masing karyawan dalam bekerja sehingga tidak akan melakukan hal buruk yang salah satunya adalah melakukan kecurangan.
2) Para manajer juga perlu terus meningkatkan pemahaman akan kesadaran pentingnya melakukan pencegahan atas faktorfaktor yang memungkinkan seseorang untuk cenderung melakukan kecurangan dalam rangka mempertahankan citra dan nama baik perusahaan di mata nasabah sehingga kepercayaan dan loyalitas nasabah tetap terjaga.

3) Para manajer yang terdapat pada BUS diharapkan terus dapat meningkatkan kesadaran dan juga pemahaman akan pentingnya religiositas, perilaku etis, dan keefektifan pengendalian internal di dalam entitas bisnis sehingga dapat bermanfaat untuk menjadi bahan pertimbangan dalam perusahaan

\section{Saran Akademis}

Saran akademis yang dapat peneliti berikan antara lain adalah sebagai berikut:

1) Penelitian selanjutnya diharapkan dapat menggunakan metode wawancara langsung dengan para responden apabila memungkinkan untuk dilakukan sehingga data yang didapatkan lebih akurat.

2) Penelitian selanjutnya diharapkan dapat menambah variabel moderasi dan variabel independen yang dapat mempengaruhi kecenderungan kecurangan akuntansi.

3) Peneliti selanjutnya diharapkan dapat memperbanyak jumlah responden dan memperbesar ruang lingkup penelitian agar penelitian kedepannya memiliki cakupan yang lebih luas, sehingga hasil yang dihasilkan lebih baik

\section{Daftar Pustaka}

Association of Certified Fraud Examiners (ACFE). (2016). Report to Nation on Occupational Fraud \& Abuse. The Association of Certified Fraud Examiners, Inc.

Basri, Yesti Mutia. (2015). Pengaruh Dimensi Budaya Dan Religiusitas Terhadap Kecurangan Pajak. Jurnal Ilmu Akuntansi. Vol.8, No.1.

Beu, D., \& Buckley, M. R. (2001). The hypothesized relationship between accountability and ethical behavior. Journal of Business Ethics. Vol. 34, No.1.

Buckley, M. R., D. S. Wiese M. G., \& Harvey. (1998). An Investigation into Dimensions of Unethical Behavior. Journal of Education for 
Bussiness. Vol.73, No.5.

Committee of Sponsoring Organizations of the Treadway Commission (COSO). (2013). The 2013 COSO Framework \& SOX Compliance.(https://www.coso.org/Pages/ic.as px). Di akses 1 mei 2019.

Egita, E., \& Siti Mahfiroh. (2018). Pengaruh Kesesuaian Kompensasi, Reward and Punishment dan Religiositas Terhadap Fraud: Studi Pada Karyawan BMT di Kabupaten Wonosobo. Jurnal Ekonomi, Bisnis, dan Akuntansi. Vol. 20, No. 04.

Ghozali, Imam. (2016). Aplikasi Analisis Multivariete Dengan Program IBM SPSS 23. Edisi Kedelapan. Semarang: Badan Penerbit Universitas Diponegoro

Glock, C. Y., \& Stark, R. (1965). Religion and Society in Tension. Chicago: Rand McNally.

Grasmick, H. G., Bursik, R. J., \& Cochran, J. K. (1991). Render unto Caesar what is Caesar's: Religiosity and taxpayers' inclinations to cheat. The Sociological Quarterly. Vol.32, No.2.

Griffin, Ricky. W., \& Ronald J. Ebert. (2007). Bisnis. Edisi Kedelapan. Jakarta: Erlangga.

Irphani, Ardi. (2017). Pengaruh Tekanan, Keefektifan Sistem Pengendalian Internal, Perilaku Tidak Etis, Dan Jabatan Dalam Pengelola Keuangan Terhadap Fraud. Thesis: Lampung: Universitas Lampung.

Junita, Nuur. (2016). Deteksi Kecurangan Laporan Keuangan Perbankan Syariah Dalam Perspektif Fraud Triangle Theory. Skripsi: Yogyakarta: Universitas Islam Negri Sunan Kalijaga Yogyakarta.

McDaniel, S. W., \& Burnett, J.J. (1990). Consumer Religiosity and Retail Store Evaluative Criteria. Journal of the Academy of Marketing Science. Vol.18, No.2.

Mulyadi. (2002). Auditing. Edisi 6. Jakarta: Salemba Empat.

Mustikasari. (2013). Faktor-faktor yang Mempengaruhi Fraud di Sektor Pemerintahan Kabupaten Batang. Accounting Analysis Journal. Vol.2, No.3.

Nurlaeliyah, siti., \& Indah, A. (2017). Analysis of Factors Affecting the Tendency of Accounting Fraud with an Ethical Behavior as Intervening Variable. Accounting Analysis Journal. Vol.6, No.2.

Otoritas Jasa Keuangan. (2017). Tentang Syariah.

(https://www.ojk.go.id/id/kanal/syariah/tentangsyariah/Pages/PB-dankelembagaan.aspx).

Diakses 18 mei 2019.
Otoritas Jasa Keuangan. (2019). Roadmap Pengembangan Keuangan Syariah Indonesia20172019. (https://www.ojk.go.id/id/ kanal/syariah/b eritadan Documents/Pages/RoadmaPengembangankeuangan-Syariah-Indonesia-20172019/Roadmap\%202017-2019(1).pdf). Diakses 18 mei 2019.

Otoritas Jasa Keuangan. (2018). Snapshot Perbankan Syariah Indonesia juni 2018.

Republik Indonesia. (2006). Peraturan Pemerintah Nomor 8 Tahun 2006 tentang Pelaporan Keuangan dan Kinerja Instansi Pemerintah.

Republik Indonesia. (2008). Undang-Undang Dasar Republik Indonesia Nomor 21 Tahun 2008 tentang Perbankan Syariah.

Rahmi, F., \& Asni, S. (2017). Dampak Sistem Pengendalian Internal, Perilaku Tidak Etis, dan Moralitas Manajemen Terhadap Kecenderungan Kecurangan Akuntansi Pada Perusahaan Developer di Pekanbaru. Journal of Islamic Economics. Vol.1, No.13.

Rohayati, Dwi. (2014). Pengaruh Kompensasi, Motivasi dan Religiositas Terhadap Kinerja Karyawan Pada BMT di Kota Salatiga dan Kabupaten Semarang. Skripsi: Salatiga: STAIN Salatiga.

Rizky, M., \& Fauziah, A. F. (2017). Pengaruh Keefektifan Pengendalian Internal,

Ketaatan Aturan Akuntansi, Penegakan Hukum, dan Perilaku Tidak Etis Terhadap Kecurangan Akuntansi. Jurnal Ilmiah Mahasiswa Ekonomi Akuntansi. Vol.2, No.2.

Suhardiyanto. (2001). Pendidikan Religiusitas. Jogjakarta: Kanisius.

Thoyibatun. (2009). Analysing the Influence of Internal Control Compliance and Compensation System against Unethical Behavior and Accounting Fraud Tendency (Studies at State University in East Java). Palembang: Simposium Nasional Akuntansi XII. 